\title{
Lean Six Sigma Methodology and Its Application in the Manufacturing Industry - A Review
}

\author{
Folorunso Olanrewaju ${ }^{1}$, Austin Chima Uzorh ${ }^{1}$, Innocent Nnanna ${ }^{2, *}$ \\ ${ }^{1}$ Deportment of Mechanical Engineering, Federal University of Technology, Owerri Nigeria \\ ${ }^{2}$ Deportment of Mechanical Engineering, Akanu Ibiam Federal Polytechnic, Unwana Nigeria
}

Email address:

innocentnnanna20@gmail.com (I. Nnanna)

*Corresponding author

\section{To cite this article:}

Folorunso Olanrewaju, Austin Chima Uzorh, Innocent Nnanna. Lean Six Sigma Methodology and Its Application in the Manufacturing Industry - A Review. American Journal of Mechanical and Industrial Engineering. Vol. 4, No. 3, 2019, pp. 40-44.

doi: 10.11648/j.ajmie.20190403.11

Received: June 22, 2019; Accepted: July 22, 2019; Published: October 11, 2019

\begin{abstract}
This paper reviewed and analyzed literature on lean six sigma (LSS) methodology tools and its applications in the manufacturing industries. Lean manufacturing deals with the process improvement and effective productivity of an organization through elimination of waste. Six sigma on the other hand, is a concept of improving plan that is capable to reduce process/operation variation of an organization. The lean-six-sigma has been practiced mostly in the developed countries along organization of time, but its importance both in the manufacturing processes and management activities cannot be neglected. The aim of this paper is to highlight the benefits of these concepts and how the two principles are merged in industries to improve productivity effectively, reduce waste, and increase the product quality level as well as ensure customer/stakeholder satisfaction. The paper also discussion various lean six sigma methodology tools adopted by small and medium scale industries to achieve improved product quality level and process or operation efficiency. This lean-six-sigma can be implemented or applied to any kind of industry for better productivity through continuous improvement on the business activities. This study would help any kind of manufacturing industry to find a solution on how to compete favorably in a competitive business environment with a dynamic market system and also equally be used by other researchers to enhance their literature.
\end{abstract}

Keywords: Lean-Six-Sigma, Lean Manufacturing, Six-Sigma, Dmaic, Vsm

\section{Introduction}

Lean-Six-Sigma involves the application of the two techniques, lean and six-sigma in the manufacturing processes for better productivity. Lean manufacturing was first adopted from the Toyota Production System in the 1980's when Toyota began its growth to a greater height in a car production business. Recently, lean-six-sigma has been rated as one of the best managerial techniques for productivity improvement.

Lean manufacturing technique is a concept adopted to eliminate those waste and processes that do not add any value to the customer satisfactions. This will equally improve the effectiveness and efficiency of the organization. On the other hand six-sigma is needed to reduce process variability. Six- sigma is a continuous improvement plan developed in the 1980's by Motorola in a quest to improve quality level by reducing variability in the manufacturing operation [1].

Lean manufacturing technique focuses its efforts on the reduction of waste and non-added value for the customer satisfactions. Six-sigma dedicates what the customer wants and best quality product to produce [2].

Mohammed [3], investigates the implementation of lean tools in construction project and its impact on safety conditions in the Gaza Strip. A questionnaire survey was undertaken with contractors and clients in order to express their attitudes on the implementation of lean tools in construction projects. The result showed a significant weakness in the application in the construction projects as well as limited information about lean construction tools. Training will be a key aspect of implementation and success 
of the lean construction techniques. However the paper demonstrated the theoretical and empirical study using Construction Company as the study area.

Richard [4], worked on the conceptual models of construction management and the tools have been criticized. This paper noted that practical and robust models techniques will help project teams to deal with the issues of wastes in projects are needed. This technique was applied in the construction Industry as lean construction methodology and the importance has been discussed. A very high level of wastes/non-value added activities exist in the construction industry which represent production cost. Lean construction aims at reducing the wastes in workflow. And also, the application of lean tools and techniques will minimize or eliminate waste, improve performance and lead to a great cost savings. This paper contributed to the knowledge and practice from delay control or waste elimination and also serve as a benchmark for continuous improvements.

Six-sigma employed statistical analysis and other qualitative tools in its efforts to identify and eliminate defects in an operation. It provides a means to find out the root cause of any problem inherent in a process.

The six sigma techniques consists of measured and reported financial results, uses additional, more advanced data analysis tools, focuses on customer concerns, and uses project management tools and methodology as presented in a paper by [5].

Thomas [6], provided the application of Six Sigma methodology within operation Department in National Bank. He focused on the establishment of the Lean Six Sigma and its impact on operation efficiency. The result of the data collected showed that, positive factors like management style, operation, and process and variation reduction were achieved due to Lean Six Sigma Implementation.

Nayan [7], worked on Six Sigma methodology which provides the techniques and tools that improved the capability and reduced the defects in a process.

Breyfogle III [8], stated that six-sigma uses some standards quality tool such as cause and effect diagram, statistical process control, pareto or control charts and benchmarking to find the root cause of the problem. Sixsigma technique helps the organization to look beyond the quality to other strategic areas to dedicate what the customer wants. Furthermore, it is observed that lean and six-sigma being on a separate page often fails to provide organizations desired improvement. While six-sigma identifies and eliminates waste, it does not however provide any means to improve or optimize system operations/ on the other hand lean technique provide means for optimizing the system but lacks the statistical analysis very much needed to improve system performance.

The above deficiencies inherent in each technique necessitate an integration of the two concepts for better improved and optimum organizational/operational result, including customer satisfaction. Ultimately, total production cost reduced, product quality improved with increased productivity.
Kanakana [9], noted that combination of two concepts (lean manufacturing and six sigma) aims to achieve total customer satisfaction and improved operational effectiveness and efficiency by removing waste and other non-value added activities.

\section{Lean-Six-Sigma Methodology}

The integration of lean manufacturing and six sigma started in 1997when BAE system first applied the two techniques in aerospace industry [10]. The company named the program lean six sigma strategy in an effort to protect market share and plan at reducing variation within the product processes. The result showed that BAE system achieved appreciable improvement in productivity, lead time, savings and reliability. Two years later, Maytag Corporationadopted the methodology to reengineered one of its production lines. This approach reduced the manufacturing cost and savings in million dollars [11].

Smith [10], stated the IBM Consulting Group experience in implementing lean-six-sigma methodology. The company used two approaches to identify the system problem. Lean technique was used to identify waste, while six-sigma was adopted to reduce variation and improve reliability.

Rockwell Automation Power System employed value stream mapping approach while applying lean techniques with $5 \mathrm{~s}$ program to ease large improvement opportunities and to implement lean flow [12]. A modified DMAIC approach was adopted in a paper documents to Electronic Copies Convention Company. At every stage of the DMAIC process, lean concepts are introduced to reduce error rate, production cost and enhance productivity [13].

Northrop Grumman Company integrated workout with Kaizen and Lean Thinking events. The company also used six-sigma methodology to validate solutions and to treat with the higher quality problems [14]. The main objective of this paper is to review lean-six-sigma methodology tools, its applications and benefits these two concepts in the manufacturing industries.

Shahrul [15], studied the implementation of new Lean Six Sigma concept. He employed Lean tools added at the analysis phase of the initiatives and used six sigma principle to reduce and then eliminate the variation found. The integrated techniques were applied in the Small Medium Enterprise (SME), particularly in the label printing industry. The development of the framework depends on the environment of the particular company in which it belongs.

The framework of the system is used in problem identification, providing suitable solutions to solve problem(s) and controlling the improvement made. This technique emphasizes on problems derived and the solutions. Conclude of this paper showed that, the adoption of the leansix-sigma framework has provided a systematic and guided approach help to identify the problem and to provide a feasible solution and sustain the improvement made.

Abdullah [17], studied the integration of lean management and six sigma strategies to improve the performance of 
production in industrial pharmaceutical. The paper evaluated factors related to the application of lean six sigma in the improvement of the management activities and performance of a selected pharmaceutical industry. This paper made an attempt to emphasis on the satisfaction of lean six sigma technique in the pharmaceutical industry.

Rathilall [18], worked on a lean six sigma framework to enhance the competitiveness in selected automotive component manufacturing organizations. The paper examines the integration of lean and six sigma tools as a unified methodology to improve and develops a functional manufacturing process in the company. The result showed that the technique offered the company great opportunity to combined operations with both tools with respect to a high quality management style and customers wants implementation.

Lean six sigma can be described as a methodology that aims on the elimination of waste and process variation through DMAIC model. This principle leads to customer satisfaction with respect to product quality, delivery time and cost implication.

The relationship between lean principles and six-sigma DMAIC model is shown in figure 1.

Benefits of Lean-Six-Sigma (Lss)

The following are the benefits of LSS:

1. Reduction in cycle time due to uniform speed and process output

2. Reduction in work-in-progress and defective products

3. Cost reduction and space saving

4. Productivity improvement
5. Improvement on customer/stakeholder satisfactions as well as reduction in delivery time

6. Less equipment and human are needed

7. Product and service development and market share growth

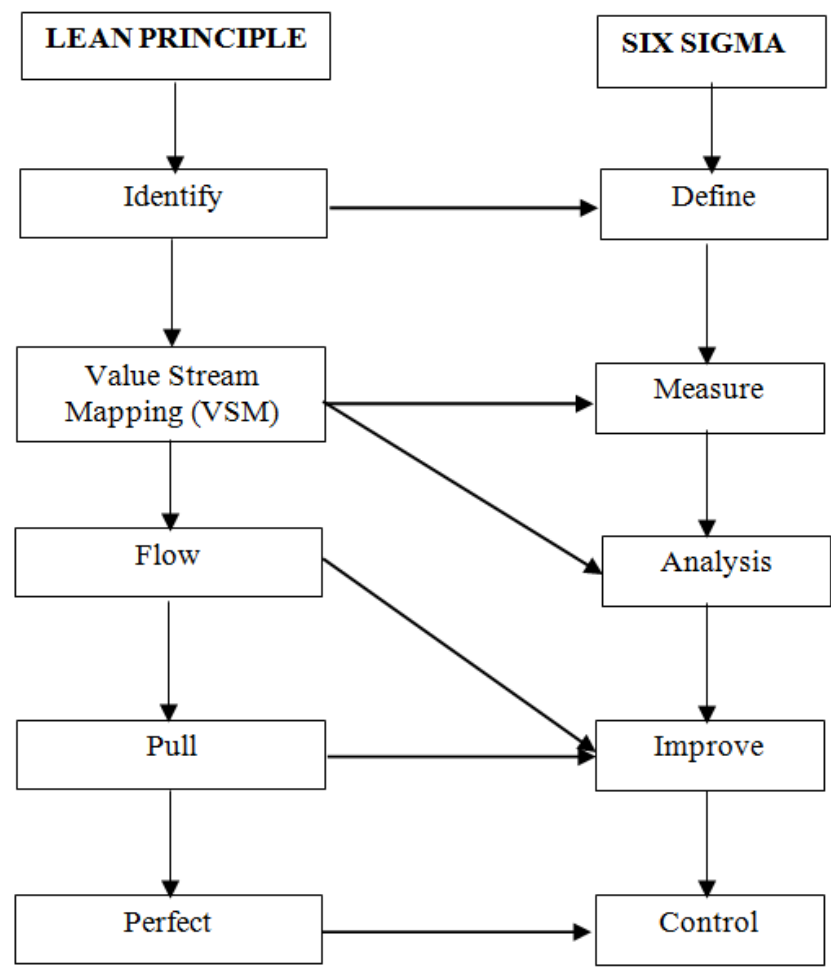

Figure 1. The relationship of Lean Principles and Six Sigma Model [16].

\section{Various Methodology Tools and Applications of Lean Six Sigma}

Table 1. Present various researchers, methodology tools and applications of lean six sigma.

\begin{tabular}{|c|c|c|c|c|c|}
\hline Author & Topic & Objective & Study Area & Methodology Tools & Result \\
\hline Abdulllah et al, 2018 & $\begin{array}{l}\text { The integration of } \\
\text { lean management and } \\
\text { six sigma strategies }\end{array}$ & $\begin{array}{l}\text { To improve the } \\
\text { performance of } \\
\text { production in a } \\
\text { Pharmacy }\end{array}$ & $\begin{array}{l}\text { Pharmaceutical } \\
\text { Industry }\end{array}$ & $\begin{array}{l}\text { Alpha Cronback and } \\
\text { Regression analysis } \\
\text { (ANOVA) }\end{array}$ & $\begin{array}{l}85.1 \% \text { in Production } \\
\text { Performance was achieved }\end{array}$ \\
\hline $\begin{array}{l}\text { Abdularkeeb et al, } \\
2017\end{array}$ & $\begin{array}{l}\text { Implementation of } \\
\text { lean six sigma } \\
\text { techniques }\end{array}$ & $\begin{array}{l}\text { To reduce cycle time, } \\
\text { defects and to increase } \\
\text { sigma level }\end{array}$ & $\begin{array}{l}\text { Small and } \\
\text { Medium scale } \\
\text { Industries }\end{array}$ & $\begin{array}{l}\text { DMAIC, VSM, SIPOC, } \\
\text { Process Capability, } \\
\text { Cause and effect diagram }\end{array}$ & $\begin{array}{l}2.3 \% \text { Sigma level with } \\
\text { increased in the net profit of } \\
\text { the company per year were } \\
\text { achieved }\end{array}$ \\
\hline $\begin{array}{l}\text { Buell and } \\
\text { Tumipseed, } 2004\end{array}$ & $\begin{array}{l}\text { Application of lean } \\
\text { six sigma in oilfield } \\
\text { operations }\end{array}$ & $\begin{array}{l}\text { To improve oilfield } \\
\text { operations business } \\
\text { performance }\end{array}$ & $\begin{array}{l}\text { Oil and Gas } \\
\text { sector }\end{array}$ & $\begin{array}{l}\text { DMAIC, Process } \\
\text { capability, Histogram }\end{array}$ & $\begin{array}{l}\text { Increase in revenue } \\
\text { generation and reduction in } \\
\text { the cost of disposing of the } \\
\text { waste }\end{array}$ \\
\hline Nabeel et al, 2011 & $\begin{array}{l}\text { Application of lean } \\
\text { six sigma tools to } \\
\text { minimize length of } \\
\text { stay for } \\
\text { ophthalmology day } \\
\text { case surgery }\end{array}$ & $\begin{array}{l}\text { To streamline processes } \\
\text { in the Ophthalmology } \\
\text { department of a local } \\
\text { hospital }\end{array}$ & Health services & DMAIC and SIPOC & $\begin{array}{l}48 \% \text { reduction in patients' } \\
\text { length of stay at the hospital } \\
\text { was achieved }\end{array}$ \\
\hline Cora et al, 2012 & $\begin{array}{l}\text { Application of the } \\
\text { enterprise } \\
\text { management tools } \\
\text { lean six sigma and } \\
\text { PMBOK }\end{array}$ & $\begin{array}{l}\text { To improve a scientific } \\
\text { research management } \\
\text { program in a general } \\
\text { hospital }\end{array}$ & Healthcare & $\begin{array}{l}\text { DMAIC, Cause and } \\
\text { effect diagram }\end{array}$ & $\begin{array}{l}\text { Sustainable improvement in } \\
\text { the managerial processes was } \\
\text { achieved }\end{array}$ \\
\hline $\begin{array}{l}\text { Mukondeleli et al } \\
2012\end{array}$ & $\begin{array}{l}\text { Applying lean six } \\
\text { sigma in Engineering }\end{array}$ & $\begin{array}{l}\text { To apply lean six sigma } \\
\text { in Engineering }\end{array}$ & $\begin{array}{l}\text { Higher } \\
\text { Education - }\end{array}$ & $\begin{array}{l}\text { DMAIC, Box plot and } \\
\text { Normality test, Pareto }\end{array}$ & $\begin{array}{l}\text { Students spent less on their } \\
\text { subjects during lecturing }\end{array}$ \\
\hline
\end{tabular}




\begin{tabular}{|c|c|c|c|c|c|}
\hline Author & Topic & Objective & Study Area & Methodology Tools & Result \\
\hline & & Education & University & $\begin{array}{l}\text { chart, Cause and effect } \\
\text { diagram, two-sample t- } \\
\text { test and Moving range } \\
\text { chart }\end{array}$ & $\begin{array}{l}\text { weeks than tests weeks. } \\
\text { Implementation of the LSS } \\
\text { increased the throughput of } \\
\text { the subjects from } 38 \% \text { to } \\
78 \%\end{array}$ \\
\hline $\begin{array}{l}\text { Jiju and Netasha, } \\
2012\end{array}$ & $\begin{array}{l}\text { Lean six sigma for } \\
\text { higher education }\end{array}$ & $\begin{array}{l}\text { To improve the } \\
\text { efficiency and } \\
\text { effectiveness of higher } \\
\text { education institutions }\end{array}$ & $\begin{array}{l}\text { Higher } \\
\text { Education - } \\
\text { University }\end{array}$ & $\begin{array}{l}\text { Value stream mapping, } \\
\text { cause and effect diagram, } \\
\text { visual management, } \\
\text { pareto chart, project } \\
\text { charter, SIPOC }\end{array}$ & $\begin{array}{l}\text { Significant efficiency and } \\
\text { effectiveness improvement in } \\
\text { the university management } \\
\text { processes }\end{array}$ \\
\hline $\begin{array}{l}\text { Alessandro et al, } \\
2012\end{array}$ & $\begin{array}{l}\text { Application of lean } \\
\text { six sigma }\end{array}$ & $\begin{array}{l}\text { To examine a number of } \\
\text { projects carried out by } \\
\text { students in Irish hospital }\end{array}$ & $\begin{array}{l}\text { Services - } \\
\text { Irish hospital }\end{array}$ & DMAIC & $\begin{array}{l}\text { Provided benefits for variety } \\
\text { of settings within the hospital }\end{array}$ \\
\hline $\begin{array}{l}\text { Ramarkrishnan and } \\
\text { Jayaprakash, } 2015\end{array}$ & $\begin{array}{l}\text { Application of lean } \\
\text { six sigma tools for } \\
\text { reduction of defects in } \\
\text { pump manufacturing }\end{array}$ & $\begin{array}{l}\text { To reduce defects in } \\
\text { pump manufacturing }\end{array}$ & $\begin{array}{l}\text { Industry - } \\
\text { pump }\end{array}$ & $\begin{array}{l}\text { Pareto chart, P-chart, } \\
\text { Run-chart, Cause and } \\
\text { effect diagram }\end{array}$ & Cost reduction \\
\hline $\begin{array}{l}\text { Elbermawy et al, } \\
2014\end{array}$ & $\begin{array}{l}\text { Implementation of } \\
\text { lean six sigma for } \\
\text { improving supply } \\
\text { chain processes }\end{array}$ & $\begin{array}{l}\text { To improve supply } \\
\text { chain processes in a } \\
\text { pharmaceutical industry }\end{array}$ & $\begin{array}{l}\text { Industry - } \\
\text { pharmacy }\end{array}$ & $\begin{array}{l}\text { DMAIC, Project charter, } \\
\text { Value stream Mapping, } \\
\text { SIPOC, Control chart, } \\
\text { Cause and effect diagram }\end{array}$ & $\begin{array}{l}\text { Reduction in lead time and } \\
\text { cycle time. Elimination of } \\
\text { over motion for physical } \\
\text { flow and non-value added } \\
\text { process. Improved } \\
\text { performance of supply chain } \\
\text { process }\end{array}$ \\
\hline $\begin{array}{l}\text { Alieja and } \\
\text { Magdalena, } 2010\end{array}$ & $\begin{array}{l}\text { Implementation of } \\
\text { management process } \\
\text { by using lean six } \\
\text { sigma tools }\end{array}$ & $\begin{array}{l}\text { To evaluate the impact } \\
\text { of lean six sigma on } \\
\text { management processes } \\
\text { in a food industry }\end{array}$ & $\begin{array}{l}\text { Industry - } \\
\text { Food }\end{array}$ & $\begin{array}{l}\text { DMAIC, VSM, } \\
\text { Visualization, 5S, Poka } \\
\text { yoke, SMED }\end{array}$ & $\begin{array}{l}\text { Cost reduction with } \\
\text { increasedprofit margin }\end{array}$ \\
\hline Adan et al, 2009 & $\begin{array}{l}\text { Implementation of six } \\
\text { sigma in a } \\
\text { manufacturing } \\
\text { process }\end{array}$ & $\begin{array}{l}\text { To identify the } \\
\text { processes that affect the } \\
\text { quality function of } \\
\text { electrical circuit } \\
\text { cartridges }\end{array}$ & $\begin{array}{l}\text { Industry - } \\
\text { Semiconductor } \\
\text { company }\end{array}$ & $\begin{array}{l}\text { DMAIC, Box diagram, } \\
\text { Cause and effect matrix, } \\
\text { ANOVA, Control chart, } \\
\text { Histogram, Normal } \\
\text { probability plot }\end{array}$ & $\begin{array}{l}\text { Reduction in the electrical } \\
\text { failures of about } 50 \% \text { with } \\
\text { better quality and other } \\
\text { features to customer } \\
\text { satisfaction }\end{array}$ \\
\hline $\begin{array}{l}\text { Ediz and Girenes, } \\
2011\end{array}$ & $\begin{array}{l}\text { Lean six sigma } \\
\text { methodology and } \\
\text { application }\end{array}$ & $\begin{array}{l}\text { To make a process lean } \\
\text { and to increase sigma } \\
\text { level }\end{array}$ & $\begin{array}{l}\text { Industry - } \\
\text { White goods }\end{array}$ & DMAIC, SIPOC & $\begin{array}{l}\text { Reduction in number of } \\
\text { defects }\end{array}$ \\
\hline Rahul et al, 2014 & $\begin{array}{l}\text { The application of } \\
\text { lean six sigma to the } \\
\text { configuration control }\end{array}$ & $\begin{array}{l}\text { To formulate strategies } \\
\text { to cater for customer } \\
\text { and stakeholder } \\
\text { satisfactions and to } \\
\text { eliminate waste }\end{array}$ & $\begin{array}{l}\text { Industry - } \\
\text { Intel's }\end{array}$ & DMAIC, SIPOC & $\begin{array}{l}60 \% \text { reduction in idle time } \\
\text { and improved } \\
\text { customer/stakeholder } \\
\text { satisfactions }\end{array}$ \\
\hline Afsheen et al, 2011 & $\begin{array}{l}\text { Application of lean } \\
\text { six sigma in } \\
\text { healthcare }\end{array}$ & $\begin{array}{l}\text { To create a baseline } \\
\text { metric of the existing } \\
\text { process for NSD in a } \\
\text { selected hospital }\end{array}$ & Healthcare & $\begin{array}{l}\text { DMAIC, Cause and } \\
\text { effect diagram, Bar chart }\end{array}$ & $\begin{array}{l}\text { Process reduction from } 39 \% \\
\text { to } 26 \% \text {, Communication } \\
\text { reduction from } 16 \% \text { to } 14 \% \text {, } \\
\text { Increase in computer-user- } \\
\text { time from } 4 \% \text { to } 12 \% \text {, Free } \\
\text { time increases from } 2 \% \text { to } \\
19 \% \text {. Proper patient care } \\
\text { established }\end{array}$ \\
\hline $\begin{array}{l}\text { Abdulaziz et al, } \\
2014\end{array}$ & $\begin{array}{l}\text { Application of lean } \\
\text { six sigma } \\
\text { methodology }\end{array}$ & $\begin{array}{l}\text { To reduce the failure } \\
\text { rate of choke valves and } \\
\text { to make } \\
\text { recommendations }\end{array}$ & $\begin{array}{l}\text { Oil and Gas } \\
\text { field }\end{array}$ & $\begin{array}{l}\text { DMAIC, SIPOC, Cause } \\
\text { and effect diagram, Bar } \\
\text { chart, Cause and effect } \\
\text { matrix, Process } \\
\text { capability, Pareto chart, } \\
\text { Failure mode and effect } \\
\text { analysis, 5-ways analysis }\end{array}$ & $\begin{array}{l}\text { Four main causes of choke } \\
\text { valves failures identified and } \\
\text { recommendations for both } \\
\text { short and long term solution } \\
\text { for each cause proposed }\end{array}$ \\
\hline $\begin{array}{l}\text { Rathilau and Signh, } \\
2018\end{array}$ & $\begin{array}{l}\text { A lean six sigma } \\
\text { frame work to } \\
\text { enhance the } \\
\text { competitiveness in } \\
\text { selected automotive } \\
\text { component }\end{array}$ & $\begin{array}{l}\text { To determine how to } \\
\text { improve on existing } \\
\text { processes for } \\
\text { automotive component } \\
\text { production }\end{array}$ & $\begin{array}{l}\text { Industry - } \\
\text { Automotive }\end{array}$ & SPSS, Cronbach's Alpha & $\begin{array}{l}\text { Low success rate of LSS } \\
\text { adoption as standalone } \\
\text { system. }\end{array}$ \\
\hline
\end{tabular}

In an effort to review and analyze previous attempt made by various researchers to integrate lean manufacturing and six-sigma, the following conclusions were drawn:
1. All the applications were carried out in the large companies, mostly in the developed countries.

2. Two-way approach implementation processes were used 
to integrate lean manufacturing and six sigma

3. Six sigma solutions were used for validation situation.

4. Complex problems were handled using lean manufacturing, while hander problems like variation control were handled by six-sigma.

5. DMAIC methodology was used for identification of compatible lean techniques.

In view of all the benefits of LSSa study was conducted using Nigerian Breweries as a study area to utilize the opportunity to improve its production line processes. Nigerian brewery is one of the largest firms in the Nigeria stock exchange. The company has high profile quality brands, including alcoholic and non-alcoholic drinks [2]. The main aim of the study is to optimize all the bottling processes to reduce waste and non-value added processes within the production lines. Results showed $37.7 \%$ reduction in lead time and other non-value added processes. A remarkable improvement in cycle time and customer satisfaction was achieved.

\section{Conclusion}

This review showed how the combination of lean manufacturing principles and six sigma tools and techniques changed both process and quality level of the product produced in the industry. The combination of the two concepts is called lean-six-sigma, a powerful tool that can influence processes and customer/stakeholder satisfaction in an organization. The lean-six-sigma has been practiced mostly in the developed countries along organization of time, but its importance both in the manufacturing processes and management activities cannot be neglected. In variant contexts, the extensive record of it has eased researchers' attentions and heightened research interest as evidenced by the current number of studies on lean-six-sigma.

This lean-six-sigma can be implemented or applied to any kind of industry for better productivity through continuous improvement on the business activities and customer/stakeholder satisfaction.

\section{References}

[1] Antonio, C. T., Fernando, J. B. L., \&Mauro de M. S. An Application of Six Sigma with Lean Production Practices for Identifying Common Causes of Software Process Variability", PICMET 2007 Proceedings, 5-9 August, Portland, Oregon 2007 PICMET, Pg: 2482-2490.

[2] Uzorh, A. C., Olanrewaju, F. \& Nnanna, I. (2018). Integration of lean manufacturing and six sigma using statistical methods. Journal of Mechanical and Civil Engineering, 15 (4), 63-76.

[3] Adnan E., \& Mohammed A. Z., (2014), "Implementation of lean tools on safety in construction projects in Palestine".
[4] Richard H. A., Shahryar S. \&SharimanB. M.., (2016), Lean construction: an effective approach for project management. Journal of Engineering and Applied Sciences. 11 (3), 18196608 .

[5] Riddhish, T., Rajat, D., Tejas P. \&Amit S. (2014). A Review: Six SigmaImplementation Practice in Manufacturing Industries, Int. Journal of Engineering Research andApplications, ISSN: 2248-9622, 4 (4), 63-69.

[6] Thomas Gachie., (2015) "The Implementation of Lean Six Sigma Concept" 19-ICIT: 7-9/4/2015.

[7] Nayan J. P. \&Darshak A. D. (2014). A Review of Six Sigma Implementation at Exporting Industries, International Journal of Emerging Technology and Advanced Engineering, 4 (3).

[8] Breyfogle III, F W. (1999). Implementing six sigma: Smarter solutions using statistical methods. Wiley, New York.

[9] Kanakana, M. G., Pretorius, J. H. C \& Van Wyk, B. Lean Six Sigma Framework to Improve Throughput rate", 978-1-42446484-5/10, 2010 IEEE.

[10] Smith, A\&Adams, A. LeanSigma SM: Advanced Quality, ASQ’s 55th Annual Quality Congress Proceedings, 2001.

[11] Dubai Quality Group. The birth of lean sigma, The Manage Mentor, Dubai. 2003.

[12] Illing, J. Seamless Integration of Lean Enterprises and Six Sigma. Automotive Manufacturing and Production, Vol. 113, No. 2, p 66, 2001.

[13] Goyal, N. Applying Lean Manufacturing to Six Sigma - A Case Study, SixSigma website, Six Sigma Article Spotlights www. isixsigma. com, 2002.

[14] McIlroy, J. \&Silverstein, D. Six Sigma Deployment in One Aerospace Company, Six Sigma Forum website www. sixsigmaforum. com, 2002.

[15] Joshua Chan RenJie, ShahrulKamaruddin and IshakAbdAzid., (2014), Implementing the Lean Six Sigma Framework in a Small Medium Enterprise (SME) January 7-9, 2014.

[16] Elbermawy, M. F., Al Manhawy A. A. \& Ibrahim, H. E. A. (2014). Implementation of Lean six sigma For Improving Supply Chain processes in a Pharmaceutical Industry. International Journal of Scientific \& Engineering Research, 5 (8), 519-529.

[17] Abdullah, A. A., Rawan, T. A. \&Feras, A. A, (2018). The integration of lean management and six sigma strategies to improve the performance of production in industrial pharmaceutical. International Journalof Business and Management, 13 (8), 207-216.

[18] Rathilall, R. \& Singh, S. (2018). A lean six sigma framework to enhance the competitiveness in selected automotive component manufacturing organizations. South African Journal of Economic and Management Sciences, 21 (1), 1-13. 